\title{
EVALUATION OF GROWTH, YIELD AND NUTRIENT CONTENT OF SOME BORO RICE CULTIVARS
}

\author{
Sharmin Akter ${ }^{1}$, Mahmud Hossain ${ }^{1^{*}}$, Azmul Huda ${ }^{1,2}$, Mohmmad Rafiqul Islam ${ }^{1}$ \\ and Mohammad Jahiruddin ${ }^{1}$
}

${ }^{1}$ Department of Soil Science, Faculty of Agriculture, Bangladesh Agricultural University, Mymensingh-2202, Bangladesh; ${ }^{2}$ Department of Soil Science, Faculty of Agriculture, Sylhet Agricultural University, Tilagore, Sylhet

*Corresponding author: Mahmud Hossain Sumon, E-mail: mahmudss2003@yahoo.com

\section{ARTICLE INFO}

ABSTRACT

Received

23.09.2014

Accepted

27.10.2014

Online

27.12.2014

Key words:

Growth

Yield

Nutrients

Boro rice
A field experiment was conducted at the Soil Science Field Laboratory of Bangladesh Agricultural University; Mymensingh during December 2012 to May 2013 to investigate the growth, yield and nutrient content of fifteen widely used boro rice cultivars of Bangladesh. The experiment was laid out in a Randomized Complete Block Design (RCBD) with 15 cultivars having each cultivar replicated three times. The cultivars tested in this experiment were BRRI dhan28, BRRI dhan29, BRRI dhan45, BRRI dhan47, BRRI dhan50, BR 3, BR 6, BR 14, BR 15, BR 16, BINA dhan5, IRATOM 24, Bachi boro, Chola boro and Sada boro. BR 15, BRRI dhan29 and BRRI dhan28 were the three rice cultivars having high potentials for grain and straw production during boro season. The highest yield was recorded 5.26 t/ha which is still very low compared to other rice growing countries of the world. So there is plenty of scope to increase the yield. Chola boro and Sada bore are two local land races having potentials for producing higher number of effective tillers and higher 1000 grain weight. Sada boro and Chola boro, two local cultivars were found very high in grain nitrogen content compared to other test cultivars. These two cultivars could be a nice tool for rice breeder to develop high nitrogen content rice. Chola boro, IRATOM 24 and BR 14 are three high straw-K containing varieties having breeding potentials to make our future rice plant strong. Before using these cultivars for breeding, fine tuning of the research findings is required.

To cite this article: S Akter, M Hossain, A Huda, MR Islam and M Jahiruddin, 2014. Evaluation of growth, yield and nutrient content of some Boro rice cultivars. Res. Agric., Livest. Fish. 1(1): 19-25. 


\section{INTRODUCTION}

Rice (Oryza sativa) is one of the leading cereal crops in the world and staple food crop in Bangladesh. It is life for more than $60 \%$ of the world's population and one of the most potential grain crops that could contribute to the efforts for the realization of food security (Gebrekidan and Seyoum, 2006). Rice alone covers $80 \%$ of the total cropped area, contributes $93 \%$ of the total grain production and is a source of $68 \%$ of the total calorie intake of the people of Bangladesh (AIS, 2008). The population of Bangladesh is growing by two million every year and may increase by another 30 million over the next 20 years. About $0.15 \%$ cultivable land of the country is going out of the agriculture sector every year due to ever increasing pressure for housing and industries for the added people. Therefore, sustaining self-sufficiency in food in the face of an ever-increasing population continues to be a major challenge for agriculturists in Bangladesh. There is very limited scope for horizontal expansion of cropping area due to limitation of land sources therefore, increase in production per unit area is the only way to increase food production. The yield of rice is quite low (3.69 $\left.\mathrm{t} \mathrm{ha}^{-1}\right)$ in Bangladesh compared to other leading rice producing countries of the world such as Japan, China, Korean republic and USA where per hectare rice yield is $9.74,6.64,6.60$, and $9.03 \mathrm{t}$, respectively (FAO, 2003). Improving soil fertility, efficient use of fertilizers, and development of high yielding nutrient efficient rice varieties are the major means to minimize the yield gap. Indigenous rice cultivars from Bangladesh as well as high yielding rice varieties possess a wide diversity in ecological, morphological, nutritional and physiological characteristics (Bhowmik et al., 2000; Islam, 1990; Jahan, 2003). There are significant differences in nitrogen utilization efficiencies among rice genotypes. Nitrogen use efficiency for rice crop productions largely ranges between $25 \%$ and $35 \%$. Exploring this capacity is an option for increasing yield as well as providing adequate nutrients to the people of rice based food diet. Therefore, along with other management practices for increasing the efficiency of applied fertilizers, the selection of efficient varieties could be a good option to minimize losses of nutrients as well as to develop high yielding nutrient use efficient varieties. Hence, the present study was carried out to evaluate the growth, yield and nutrient content potentials of some boro rice varieties.

\section{MATERIALS AND METHOD}

The experiment was carried out in the Soil Science Field Laboratory of Bangladesh Agricultural University, Mymensingh during Boro season (December 2012 to May 2013). The study was performed to evaluate the growth, yield and nutrient content of some boro rice cultivars. The soil of the experimental site belongs to the Sonatala series under the AEZ of Old Brahmaputra Floodplain. The soil was silt loam in texture having $\mathrm{pH} 6.13$, organic matter $1.62 \%$, total $\mathrm{N} 0.113 \%$, available $\mathrm{P}$ $7.03 \mathrm{ppm}$, exchangeable $\mathrm{K} 0.069 \mathrm{me} \%$ and available S $12.2 \mathrm{ppm}$. The experiment was laid out in a Randomized Complete Block Design (RCBD) with fifteen rice cultivars and each cultivar replicated three replications. The cultivars used in the experiment were: $V_{1}-B R 3, V_{2}-B R 6, V_{3}-B R 14, V_{4}-$ BR 15, V5- BR 16, $V_{6}-$ BRRI dhan28, $V_{7}-$ BRRI dhan29, $V_{8}-$ BRRI dhan45, $V_{9}-$ BRRI dhan47, $V_{10}$ BRRI dhan50, V11- IRATOM 24, V12- BINA 5, V13- Chola boro, $V_{14}$ - Sadaboro and $V_{15}$ - Bachiboro.

The rice cultivars were planted in a single line having one check cultivar (BRRI dhan28) in between two test cultivars. Each line of the test and check cultivars had ten hills with a hill to hill distance of $20 \mathrm{~cm}$, the line to line distance was also $20 \mathrm{~cm}$. All the fertilizers except urea i.e. TSP, MoP, gypsum and zinc sulphate were applied as basal doses in all the plots at final land preparation. Prilled urea was applied in three equal splits. Forty-eight days old seedlings were transplanted. The first dose of urea was applied at 7 days after transplanting (DAT), the second dose was applied at 41 DAT and the third dose was applied at 56 DAT. Different intercultural operations such as irrigation, weeding, pest control etc. were done as and when required. 
The crop was harvested plot wise at full maturity and the data on plant height, panicle length, number of effective tillers hill ${ }^{-1}$, number of filled grain panicle ${ }^{-1}$, number of unfilled grain panicle ${ }^{-1}$, 1000 grain weight, grain and straw yields were recorded. The grain and straw samples were analyzed for N, P and K content and uptake. All the data were statistically analyzed by F-test and the mean differences were adjudged by Duncan's Multiple Range Test (DMRT) using statistical package, Minitab.

\section{RESULTS AND DISCUSSION}

\section{Yield attributes}

The yield attributes of different boro rice cultivars were significantly influenced except panicle length even with the same fertilizer management. There was a significant variation in the number of effective tillers hill ${ }^{-1}$ among the boro rice cultivars (Table 1 ). The maximum number of effective tillers hill-1 (16) was found in Chola boro which was statistically significant over rest of the cultivars. Bhowmick and Nayak (2000) also reported remarkable variations in tillering between the varieties in a field study. Plant height of boro rice was also significantly varied between the cultivars in the experiment (Table 1). The tallest plants $(98.1 \mathrm{~cm})$ were found in Sada boro and the shortest plants $(59.9 \mathrm{~cm})$ were found in IRATOM 24. There was no significant variation among the boro rice cultivars in terms of panicle length. The number of filled grain production was found statistically significant between the cultivars (Table 1 ).

The number of filled grains panicle ${ }^{-1}$ varied from 33 to 117 . The highest number of filled grains panicle ${ }^{-1}$ was found in BR 15 and that of the lowest was found in Chola boro. The highest number of unfilled grains panicle-1 was in BR 14 (22) which was statistically identical to rest of the varieties except BR 3, BRRI dhan47 and the three local cultivars. The 1000-grain weight of rice ranged from 18.6 to $25.9 \mathrm{~g}$. The highest 1000 -grain weight of $25.9 \mathrm{~g}$ was found in Chola boro and that of the lowest was noted in BRRI dhan50 (18.6).

Table 1. Yield contributing characters of different boro rice cultivars under same fertilization

\begin{tabular}{|lllllll|}
\hline Treatments & $\begin{array}{l}\text { Effective } \\
\text { tillers } \\
\text { Ihill (No.) }\end{array}$ & $\begin{array}{l}\text { Plant height } \\
\mathbf{( c m})\end{array}$ & $\begin{array}{l}\text { Panicle } \\
\text { Length } \\
\mathbf{( c m )}\end{array}$ & $\begin{array}{l}\text { Filled grainsl } \\
\text { panicle (No.) }\end{array}$ & $\begin{array}{l}\text { Unfilled } \\
\text { grainsl } \\
\text { panicle (No.) }\end{array}$ & $\begin{array}{l}\text { 1000-grain } \\
\text { weight (g) }\end{array}$ \\
\hline BR 3 & $9.35 \mathrm{bc}$ & $59.93 \mathrm{f}$ & 20.44 & $52.79 \mathrm{ef}$ & $11.39 \mathrm{bcd}$ & $25.60 \mathrm{ab}$ \\
BR 6 & $9.80 \mathrm{bc}$ & $71.58 \mathrm{def}$ & 21.91 & $54.50 \mathrm{def}$ & $15.17 \mathrm{abc}$ & $24.10 \mathrm{abcd}$ \\
BR 14 & $8.46 \mathrm{bc}$ & $79.6 \mathrm{bcd}$ & 21.62 & $58.52 \mathrm{cdef}$ & $21.59 \mathrm{a}$ & $24.20 \mathrm{abcd}$ \\
BR 15 & $8.11 \mathrm{bc}$ & $77.7 \mathrm{bcde}$ & 23.47 & $117.02 \mathrm{a}$ & $20.58 \mathrm{a}$ & $21.25 \mathrm{efg}$ \\
BR 16 & $8.77 \mathrm{bc}$ & $74.55 \mathrm{de}$ & 22.46 & $84.29 \mathrm{bcd}$ & $15.93 \mathrm{abc}$ & $22.40 \mathrm{def}$ \\
BRRI dhan28 & $9.66 \mathrm{bc}$ & $78.09 \mathrm{bcd}$ & 22.84 & $84.41 \mathrm{bc}$ & $10.13 \mathrm{~cd}$ & $23.80 \mathrm{bcd}$ \\
BRRI dhan29 & $10.06 \mathrm{bc}$ & $72.91 \mathrm{de}$ & 23.01 & $100.00 \mathrm{ab}$ & $20.31 \mathrm{ab}$ & $22.60 \mathrm{def}$ \\
BRRI dhan45 & $9.66 \mathrm{bc}$ & $75.10 \mathrm{cde}$ & 20.18 & $61.91 \mathrm{cdef}$ & $11.21 \mathrm{~cd}$ & $24.00 \mathrm{abcd}$ \\
BRRI dhan47 & $7.60 \mathrm{c}$ & $79.63 \mathrm{bcd}$ & 23.39 & $78.18 \mathrm{bcde}$ & $21.02 \mathrm{a}$ & $25.00 \mathrm{abc}$ \\
BRRI dhan50 & $9.66 \mathrm{bc}$ & $66.01 \mathrm{ef}$ & 22.42 & $54.62 \mathrm{ef}$ & $21.36 \mathrm{a}$ & $19.50 \mathrm{~h}$ \\
IRATOM 24 & $8.33 \mathrm{bc}$ & $59.86 \mathrm{f}$ & 19.23 & $56.53 \mathrm{cdef}$ & $17.34 \mathrm{abc}$ & $23.70 \mathrm{~cd}$ \\
BINA 5 & $8.93 \mathrm{bc}$ & $71.95 \mathrm{de}$ & 20.49 & $59.09 \mathrm{cdef}$ & $17.01 \mathrm{abc}$ & $22.90 \mathrm{bcde}$ \\
Chola boro & $16.20 \mathrm{a}$ & $89.41 \mathrm{ab}$ & 19.07 & $33.8 \mathrm{f}$ & $5.4 \mathrm{~d}$ & $25.95 \mathrm{a}$ \\
Sada boro & $11.73 \mathrm{~b}$ & $98.13 \mathrm{a}$ & 22.50 & $57.30 \mathrm{cdef}$ & $5.5 \mathrm{~d}$ & $19.60 \mathrm{gh}$ \\
Bachi boro & $6.53 \mathrm{c}$ & $86.88 \mathrm{abc}$ & 19.22 & $57.58 \mathrm{cdef}$ & $11.54 \mathrm{bcd}$ & $20.85 \mathrm{fgh}$ \\
\hline$p$ value & $<0.001$ & $<0.001$ & 0.08 & $<0.001$ & $<0.001$ & $<0.001$ \\
\hline
\end{tabular}

Figures in a column having common letters do not differ significantly at $5 \%$ level of significance 


\section{Grain yield}

Grain yield of boro rice cultivars varied significantly in the experiment (Figure 1). The grain yield ranged from 1.74 to $5.26 \mathrm{t} / \mathrm{ha}$. Borah and Deka (1994) reported a great variation in grain yield, $\mathrm{N}$ uptake, translocation efficiency and $\mathrm{N}$ use efficiency among rice varieties. The highest grain yield of 5.26 t/ha was recorded in BR 15 which was statistically similar to Sada boro, BR3, Chola boro, BINA 5, BR6, IRATOM 24, BR14 and Bachi boro. The lowest value of 1.74 t/ha was recorded in Bachi boro. Bose et al. (2005) reported that high genotypic co-efficient of variation was observed for plot yield. The varieties may be ranked in the order of BR 15> BRRI 29> BRRI dhan $45>$ BRRI dhan50> BRRI dhan47> BR $14>$ BR 16> Sada boro $>$ BR $3>$ Chola boro $>$ BINA $5>$ BR 6> IRATOM $24>$ BR 14> Bachi boro in terms of grain yield.

\section{Straw yield}

The straw yield of different boro rice cultivars also performed different at same fertilizer application (Figure 1). The straw yield observed in different varieties ranged from 1.93 to $4.81 \mathrm{t} / \mathrm{ha}$. The highest straw yield of $4.81 \mathrm{t} / \mathrm{ha}$ was obtained in BRRI dhan29 which was statistically similar to BR 15, Chola boro, BR 16, BINA 5, Sada boro and BR3. The lowest straw yield (1.93t/ha) was noted in IRATOM 24. The varieties may be ranked in the order of BRRI dhan 29> BR 15> Chola boro $>$ BR 16> BINA $5>$ Sada boro $>$ BR 3> BRRI dhan47> BRRI dhan28> BR 14> BRRI dhan50> BR $6>$ BRRI dhan45 > Bachi boro> IRATOM 24 in terms of straw yield.

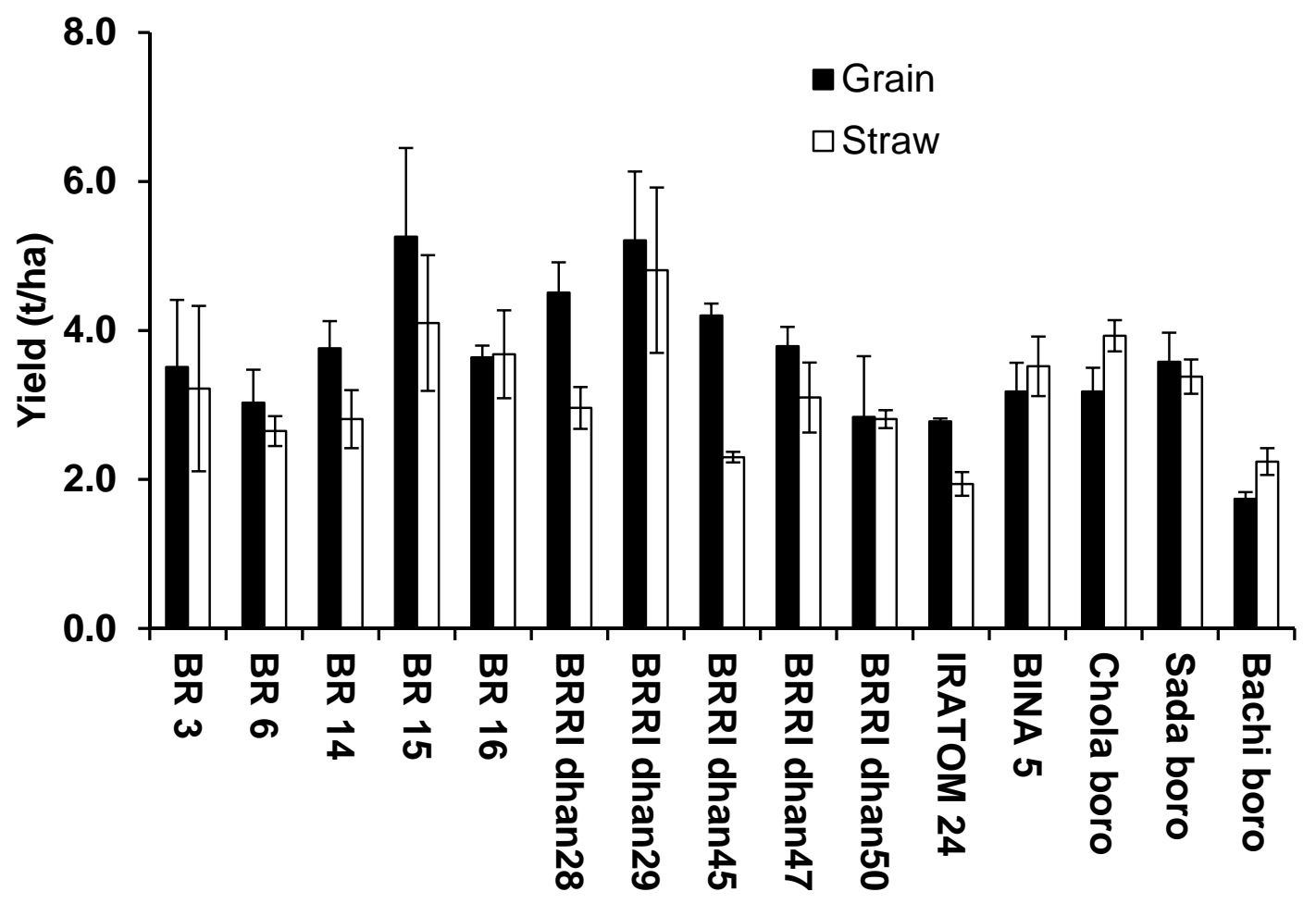

Figure 1. Grain and straw yields of Boro rice cultivars under same fertilization

\section{NPK content and uptake}

The boro rice cultivars used in the experiment showed numerical variations in nitrogen content of grain and straw though the variations were not statistically significant (Table 2). Sada boro was found very high in grain $\mathrm{N}$ content compared to other test cultivars having gain $\mathrm{N} 1.76 \%$. Hassan et 
al. (2009) reported that Basfulehikon as a high grain $\mathrm{N}$ content rice cultivar (1.53\%) and some others were very close to it. The $\mathrm{N}$ uptake in grain and straw of boro rice varieties did not vary significantly. The highest $\mathrm{N}$ uptake in grain $(62.67 \mathrm{~kg} / \mathrm{ha})$ was observed in Sada boro and in straw $(21.11 \mathrm{~kg} / \mathrm{ha})$ was observed in BRRI dhan29 and the lowest N uptake in grain $(18.45 \mathrm{~kg} / \mathrm{ha})$ was obtained in Bachi boro and in straw (8.99 kg/ha) was obtained in BRRI dhan45.

Table 2. Nitrogen content and uptake in boro rice cultivars

\begin{tabular}{|c|c|c|c|c|c|}
\hline \multirow{2}{*}{ Treatments } & \multicolumn{2}{|c|}{$\mathrm{N}$ content $(\%)$} & \multicolumn{2}{|c|}{$\mathrm{N}$ uptake $(\mathrm{kg} / \mathrm{ha})$} & \multirow{2}{*}{$\begin{array}{c}\text { Total N uptake } \\
\text { (kg/ha) }\end{array}$} \\
\hline & Grain & Straw & Grain & Straw & \\
\hline BR 3 & 1.12 & 0.50 & 33.66 & 12.98 & 46.65 \\
\hline BR 6 & 1.34 & 0.50 & 42.08 & 13.90 & 55.99 \\
\hline BR 14 & 0.81 & 0.42 & 30.34 & 12.44 & 42.79 \\
\hline BR 15 & 0.92 & 0.58 & 43.36 & 20.66 & 63.92 \\
\hline BR 16 & 1.06 & 0.47 & 37.83 & 16.07 & 53.84 \\
\hline BRRI dhan28 & 1.03 & 0.50 & 46.00 & 14.89 & 60.89 \\
\hline BRRI dhan29 & 0.84 & 0.50 & 40.27 & 21.11 & 61.38 \\
\hline BRRI dhan45 & 1.00 & 0.39 & 44.26 & 8.99 & 48.13 \\
\hline BRRI dhan47 & 0.98 & 0.39 & 33.76 & 11.23 & 46.99 \\
\hline BRRI dhan50 & 1.40 & 0.3 & 25.40 & 9.44 & 40.21 \\
\hline IRATOM 24 & 1.06 & 0.53 & 29.88 & 10.75 & 40.64 \\
\hline BINA 5 & 1.17 & 0.50 & 27.70 & 15.40 & 54.13 \\
\hline Chola boro & 1.45 & 0.36 & 48.99 & 13.89 & 62.89 \\
\hline Sada boro & 1.76 & 0.47 & 62.67 & 16.79 & 79.46 \\
\hline Bachi boro & 1.06 & 0.44 & 18.45 & 9.93 & 28.38 \\
\hline$p$ value & 0.675 & 0.757 & 0.479 & 0.138 & 0.237 \\
\hline
\end{tabular}

Table 3. Phosphorus content and uptake in boro rice varieties

\begin{tabular}{|lccccc|}
\hline \multirow{2}{*}{ Treatments } & \multicolumn{2}{c}{$\mathbf{P}$ content (\%) } & \multicolumn{2}{c|}{$\mathbf{P}$ uptake $\mathbf{( \mathbf { k g ~ h a } ^ { - \mathbf { 1 } } )}$} & Total P uptake \\
\cline { 2 - 5 } & Grain & Straw & Grain & Straw & (kg/ha) \\
\hline BR 3 & 0.21 & 0.057 & 6.78 & 1.50 & 8.29 \\
BR 6 & 0.22 & 0.064 & 6.69 & 1.76 & 8.46 \\
BR 14 & 0.23 & 0.074 & 9.15 & 2.26 & 11.42 \\
BR 15 & 0.16 & 0.063 & 7.92 & 2.45 & 10.37 \\
BR 16 & 0.17 & 0.068 & 6.14 & 2.27 & 8.42 \\
BRRI dhan28 & 0.18 & 0.078 & 8.42 & 2.25 & 10.67 \\
BRRI dhan29 & 0.21 & 0.069 & 10.12 & 2.95 & 13.07 \\
BRRI dhan45 & 0.15 & 0.067 & 9.81 & 1.81 & 11.32 \\
BRRI dhan47 & 0.21 & 0.048 & 7.80 & 1.40 & 9.20 \\
BRRI dhan50 & 0.22 & 0.063 & 6.64 & 2.86 & 5.54 \\
IRATOM 24 & 0.21 & 0.060 & 6.12 & 1.22 & 7.34 \\
BINA 5 & 0.19 & 0.080 & 6.43 & 2.60 & 7.82 \\
Cholaboro & 0.18 & 0.069 & 5.85 & 2.65 & 8.51 \\
Sadaboro & 0.15 & 0.053 & 5.77 & 1.86 & 7.63 \\
Bachiboro & 0.16 & 0.050 & 2.83 & 1.13 & 3.97 \\
\hline p value & 0.974 & 0.436 & 0.270 & 0.173 & 0.225 \\
\hline
\end{tabular}


Results in Table 3 show that phosphorus content in grain and straw of boro rice cultivars did not vary significantly though the numerical variations seems quite remarkable. The highest $P$ content in rice grain was observed in BR 14 and that of the lowest was observed in BRRI dhan 45. The highest $P$ content in rice straw was found in BINA dhan5 (0.08\%) and the lowest $P$ content in rice straw was found in BRRI dhan47 (0.05\%). The results presented in Table 3 show that $P$ uptake both in grain and straw of boro rice did not vary significantly among the varieties. The maximum $P$ uptake in grain and straw was found in BRRI dhan29 and the lowest $P$ uptake by grain and straw was found in Bachi boro. The potassium content in grain and straw of boro rice cultivars also did not vary significantly (Table 4). The highest $\mathrm{K}$ content in rice grain was recorded in BINA dhan5 and that in straw was recorded in Chola boro. The $\mathrm{K}$ uptake in grain and straw of boro rice did not vary significantly among the test cultivars (Table 4). The $\mathrm{K}$ uptake by grain ranged from 5.43 to $17.30 \mathrm{~kg} / \mathrm{ha}$ and that by straw ranged from 58.29 to $142.19 \mathrm{~kg} / \mathrm{ha}$. The total $\mathrm{K}$ uptake by grain and straw also did not vary among the test cultivars with same fertilizer application. The varieties may be ranked in the order of Chola boro $>$ BR 15> BRRI dhan29> BINA 5> BR 14> BRRI dhan28> BR 16> BRRI dhan47> Sada boro> BRRI dhan50> IRATOM 24> BRRI dhan45> BR 16> Bachi boro> $\mathrm{BR} 3$ in terms of total $\mathrm{K}$ uptake. The results indicate huge $\mathrm{k}$ depletion from soil due to rice cultivation which needs to be addressed when recommending $\mathrm{K}$ fertilizer for rice.

Table 4. Potassium content and uptake in boro rice cultivars

\begin{tabular}{|lccccc|}
\hline \multirow{2}{*}{ Treatments } & \multicolumn{2}{c}{ K content (\%) } & \multicolumn{2}{c|}{ K uptake (kg/ha) } & \multirow{2}{*}{ Total K uptake (kg/ha) } \\
\cline { 2 - 5 } & Grain & Straw & Grain & Straw & \\
\hline BR 3 & 0.35 & 2.27 & 10.90 & 58.29 & 69.19 \\
BR 6 & 0.34 & 2.53 & 10.46 & 69.91 & 80.37 \\
BR 14 & 0.41 & 3.65 & 15.75 & 109.37 & 125.12 \\
BR 15 & 0.29 & 3.49 & 14.12 & 131.39 & 145.51 \\
BR 16 & 0.32 & 2.81 & 11.67 & 94.44 & 106.11 \\
BRRI dhan 28 & 0.31 & 3.20 & 14.41 & 95.20 & 109.61 \\
BRRI dhan 29 & 0.35 & 2.58 & 17.21 & 108.88 & 126.09 \\
BRRI dhan 45 & 0.31 & 2.76 & 17.30 & 92.93 & 80.84 \\
BRRI dhan 47 & 0.36 & 3.05 & 13.48 & 87.36 & 100.84 \\
BRRI dhan 50 & 0.37 & 2.66 & 5.43 & 74.86 & 86.13 \\
IRATOM 24 & 0.35 & 3.65 & 10.07 & 73.72 & 83.97 \\
BINA 5 & 0.48 & 3.59 & 9.28 & 109.99 & 125.91 \\
Chola boro & 0.24 & 3.72 & 7.76 & 142.19 & 149.95 \\
Sada boro & 0.42 & 2.32 & 15.41 & 81.70 & 97.11 \\
Bachi boro & 0.37 & 2.87 & 6.59 & 64.46 & 71.05 \\
\hline$p$ value & 0.425 & 0.053 & 0.051 & 0.058 & 0.084 \\
\hline
\end{tabular}

\section{CONCLUSIONS}

Finally, it can be concluded that BR15, BRRI dhan29 and BRRI dhan28 are the three rice cultivars having high potentials for grain and straw production. Chola boro and Sada boro are two local land races having potentials for producing higher number of effective tillers and bigger grain producing cultivars. Sada boro was found to have very high grain N. Therefore, this cultivar could be a tool for rice breeders to develop high $\mathrm{N}$ containing rice. Chola boro, IRATOM 24 and BR 14 are three high straw-K containing varieties having breeding potentials to make our future rice plant strong. 


\section{REFERENCES}

1. AIS (Agriculture Information Service), 2008. Krishi Diary, AIS, Ministry of Agriculture, and Government of People's Republic of Bangladesh.

2. Bhowmick $\mathrm{N}$ and RL Nayak, 2000. Response of hybrid rice (Oryza sativa L.) genotypes to nitrogen phosphorus and potassium fertilizers during dry (boro) season in West Bengal. Indian Journal of Agronomy 45: 323-326.

3. Borah RC and SC Dek, 1994. Variation in uptake, assimilation and use efficiency of nitrogen of low land Aus rice. Journal of Agricultural Science North-East India 7: 92-94.

4. Bose LK, SK Pradhan, A Mohanty, M Nogaraju, 2005. Genetic variability and association of yield attributing characters with grain yield in deep water rice. Korean Journal of Crop Science 50: 262264.

5. FAO, 2003. Production Year Book. Food and Agriculture Organization of the United Nations, Rome, Italy.

6. Gebrekidan $\mathrm{H}$ and $\mathrm{M}$ Seyoum, 2006. Effects of mineral $\mathrm{N}$ and $\mathrm{P}$ fertilizers on yield and yield Components of flooded lowland rice on Vertisols of Fogera plain, Ethiopia. Journal of Agriculture and Rural Development in the Tropics and Subtropics. 107: 161-176.

7. Hassan MS, A Khair, MM haque, AK Azad and A Hamid, 2009. Genotypic variation in traditional rice varieties for chlorophyll content, spad value and nitrogen use efficiency. Bangladesh Journal of Agricultural Research. 34(3): 505-515.

8. Islam QR, 1990. Ecological and physiological studies on Bangladesh deep water rice. Bulletin, Institute of Tropical Agriculture, Kyushu University, 13: 1-93.

9. Jahan MS, T Kumamaru, A Hamid and H Satoh, 2003. Diversity of grain quality characters in Bangladesh rice germplasm. Khulna University Studies, 5: 71-77. 